\title{
Strengthening Role and Policy of Local Government in Accelerating Development of Social Forestry in East Kalimantan
}

\author{
Tien Wahyuni ${ }^{1, *}$ \\ ${ }^{1}$ Research and Development Centre for Dipterocarps Forest Ecosystems. Jl A.W. Syahrani, Samarinda 75124, East \\ Kalimantan, Indonesia. \\ *Corresponding author. Email: yunitien@hotmail.com
}

\begin{abstract}
The implementation of The Green Growth Compact (GGC) movement in East Kalimantan is in synergy with the Social Forestry (SF) Program, which is being rolled out and become a government priority program. The following paper aims to provide an overview of how the strengthening of local government roles and policies accelerates SF's development and identifies potential barriers and proposed policies towards accelerated growth. Data collection through document studies, interviews, and observations using content analysis. The research results show that SF policies and regulations have not been entirely directed to simplify the operational level's licensing process. An effort to accelerate SF's development is to intensify communication and coordination between the Ministry of Environment and Forestry with the local government and communications with the community and with its counselors in the field. There are some policy interventions identified in supporting the acceleration of social forestry. While the proposed policies to overcome barriers that will keep SF's success are investment policies of SF activities, operational procedures, and enabling and policy-legislation.
\end{abstract}

Keywords: Green Growth Compact, Social Forestry, Content Analysis, Policy Intervention

\section{INTRODUCTION}

Following reforms in 1998, forestry conflicts in Indonesia did not show any decline either quantitatively or qualitatively. Based on data from Forest Watch Indonesia (FWI) and the Center for International Forestry Research (CIFOR), between 1997 and 2003, 359 cases of forest conflict occurred, mostly in East Kalimantan, followed by Central Java, North Sumatra, and West Java [1]. In the post-reform period, forestry conflicts increased elevenfold compared to 1997, from 14 cases to 53 cases in 2000 . Of the total conflicts, $39 \%$ were in the industrial plantation area (HTI), 27\% in concessions (HPH), and $34 \%$ in conservation areas. HuMa (2012) recorded 349 cases of natural resource conflicts; 95 cases $(27.22 \%)$ were forestry cases. In 2015, the Agrarian Reform Consortium recorded 52,176 ha of forest conflict, the second largest after the plantation conflict of 302,526 ha (WALHI 2016).

As a solution to solve forestry conflicts, approaches are (1) opening and providing legal access to forest communities to utilize and manage forest areas as their economic support, as well as addressing tenurial uncertainties over forest areas and (2) community capacity building to be able to utilize forest resources that are managed and used sustainably in supporting their life and livelihood. Government-initiated SF programs can be effective solutions to agrarian conflicts, poverty alleviation tools, reduction of deforestation, and strengthening of forest governance by incorporating local needs, knowledge, and practices. There are five forms of legality in social forestry initiated since 1998, namely Community Forest Utilization Permit (IUPHKm), Village Forest Management Rights (HPHD), Timber Forest Product Utilization Permit (IUPHHK-HTR), Forestry Partnership, and Determination Indigenous Forest.

In the 2015 - 2019 National Medium-Term Development Plan (RPJMN), there has been a target of 2.5 million hectares of social forest area every year or 12.7 million hectares until 2019, covering 9,800 villages. The Ministry of Environment and Forestry 
(KLHK) has issued Ministerial Regulation no. 83 of 2016 on Social Forestry to achieve the target. To outline this regulation by taking a strategic step, namely by making some policy revisions to simplify the licensing procedure; the establishment of Indicative Maps of Social Forestry Areas (PIAPS); licensing service online, and the establishment of the Working Group on the Acceleration of Social Forestry (Pokja PPS) in each province. With this strategic step is expected, SF can achieve goals and on target.

As the province with the largest forest in Indonesia with large forested areas, East Kalimantan has found much poverty [2]. Currently, the Government of East Kalimantan targets 660,782 hectares for SF activities scattered in various districts, and areas of such actions will undoubtedly be regulated in the Regional Regulation (Perda) Spatial Plans of the Year 2016.

The drive for innovation and the role of policies and regulations that support the acceleration of SF's implementation are fundamental and necessary. The long-term utilization and management of SF areas will motivate stakeholders to conserve and improve forest management and develop SF by maintaining existing forests for the benefit and well-being of communities in and around forests, national interests, and global interests. East Kalimantan's local government expects a participatory approach and synergizes with many parties to develop the SF in various schemes to encourage SF development's acceleration. However, some potential problems and obstacles are still a constraint in developing SF, so it is necessary to identify potential barriers and proposed policies to encourage successful SF development in East Kalimantan.

\section{METHODS}

\subsection{Study Area}

This research was conducted in East Kalimantan province (Figure 1). The selection of provinces is made purposively because the policy is more conical at the provincial level, considering the development of SF development and activities expected to contribute to regional development. This research was conducted during 2015 - 2017.

\subsection{Data Collection Method}

\subsubsection{Primary Data}

Primary data were collected from focus group discussions (FGD), seminars, or other meetings with stakeholders at the local level, as well as from interviews with personal experts who considered experts and in-depth understanding of the development of social forestry issues, such as related officials, academics and researchers, businessman or other parties.

Table 1. Method of data and information collection.

\begin{tabular}{|c|c|c|c|}
\hline No. & Methods & Source data/respondents & Data type \\
\hline 1. & FGD, recording & Government institutions & $\begin{array}{l}\text { Regulatory documents supporting the } \\
\text { acceleration of social forestry development }\end{array}$ \\
\hline 2. & Interview & $\begin{array}{l}\text { Government institutions, } \\
\text { community representatives }\end{array}$ & $\begin{array}{l}\text { Data on the progress of social forestry } \\
\text { development }\end{array}$ \\
\hline 3. & Field observation & Community representatives & $\begin{array}{l}\text { Site condition, socio-economic condition, } \\
\text { and community culture }\end{array}$ \\
\hline 4. & FGD & The parties concerned & $\begin{array}{l}\text { Data and information on the development of } \\
\text { social forestry }\end{array}$ \\
\hline
\end{tabular}

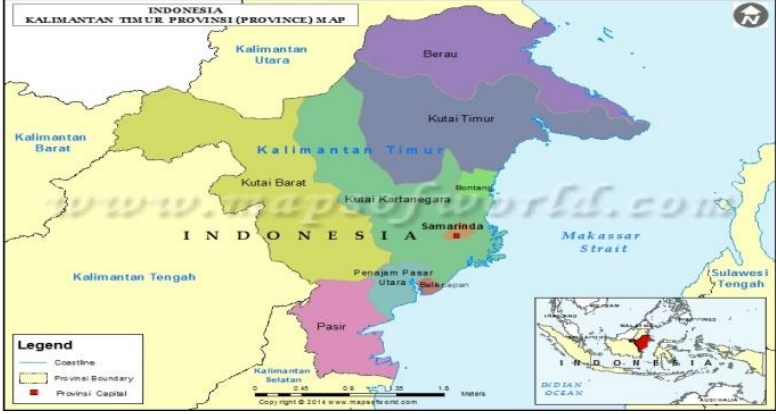

Figure 1 East Kalimantan Map.

\section{RESULTS AND DISCUSSION}

\subsection{Urgency of Social Forestry Development in East Kalimantan}

East Kalimantan (Kaltim) is one of five provinces in the eastern tip of Borneo's island, which has a position at the east end that directly borders the states of Sabah and Sarawak, East Malaysia, West Kalimantan, South Kalimantan, Central Kalimantan and North Kalimantan. East Kalimantan has 12,773,881.80 hectares with a forest area of 8,333,294.83 hectares and a population of 3.6 million. East Kalimantan is the fourth most densely 
populated region in Indonesia. Before the bloom became North Kalimantan, East Kalimantan is the second largest province in Indonesia after Papua with an area of $194.489 \mathrm{~km}^{2}$, almost the same as the island of Java or about $6.8 \%$ the total area of Indonesia.

East Kalimantan has committed to realize the sustainable green development that has been proclaimed since 2010 in the Kaltim Green movement as a green province. Again, East Kalimantan declared a significant move in the Green Growth Compact (GGC) to reinforce this commitment. GGC is a committee formed by involving the parties, namely government, private, and community, to encourage green development that balances economic and environmental interests. This GGC is reinforced and declared by the Ministry of Environment and Forestry (KLHK) on September 27, 2016, in Jakarta.GGC is expected to inspire other areas of Indonesia, which are practiced in East Kalimantan, and contribute well to other green development regions. GGC also synergizes with the concept of social forestry, a sustainable forest management system in state forest areas or forest rights or customary forest managed and utilized by the local community or customary law community as the main actors to improve their welfare.

In addition, East Kalimantan is echoing social forestry's development in the community with the jargon of 'Building Social Forestry in East Kalimantan'. This effort is made to offset the bids' rate for developing oil palm plantations or mining (especially coal). Both businesses have even started to enter the forest area or convert the community's traditional practices to manage or cultivate forest and forest products. If it is allowed to continue, it will be too late or difficult to preserve forest resources, which currently decrease by more than a third [3].

\subsection{The Role of Development Policy and Development of Social Forestry in East Kalimantan}

Circular Letter (SE) of the Ministry of Environment and Forestry (KLHK) on December 5, 2016, on Village Forest Management Rights (HPHD), Community Forest Utilization Permit (IUPHKm), and Timber Forest Product Utilization License in Community Plantation Forest (IUPHHK-HTR) by the Governor; is an effort to demonstrate that the government seeks to establish communication and coordination with the local government, the community and with its facilitators in the field, to harmonize understanding, in addition to supporting the allocation of funding about the responsibilities imposed by the local government under prevailing laws and regulations. It is expected that Governor (1) may incorporate social forestry programs in the Medium Term Development Plan (RPJMD); (2) make the Governor's Regulation on social forestry programs and (3) provide budget support for social forestry programs through the Regional Budget (APBD) and or through the revenue sharing-Reforestation Fund.

The local government of East Kalimantan also shows the strategic effort to accelerate the development of SF in the formation of the Working Group on Social Forestry Acceleration (Pokja PPS) based on the Decision of the Governor of East Kalimantan. 522/K.526/ 2016, dated September 14, 2016, consists of three divisions, namely (1) acceleration of forest access granting; (2) capacity building and business development of SF and (3) community and advocacy of SF.

Some related local regulations and support the specific green development and social forestry development that the East Kalimantan Regional Government can be seen in Table 2. Provincial regulatory policies on the SF should be more detailed, and the regions will try to develop their respective regional policies according to local potentials and demands. More detailed regulations should be delegated to the village level with the field's facilitators' assistance on a legal basis. 
Table 2. Local Regulations and Policies That Support Social Forestry Development in East Kalimantan

\begin{tabular}{lll}
\hline No. & \multicolumn{1}{c}{ Regulation } & Target \\
\hline 1. & Regional regulation No. 15 / 2008 on Regional The fulfillment of electricity supply reliable and efficient \\
& Long Term Development Plan of East \\
& Kalimantan Province $2005-2025$ \\
2. & Regional regulation No. $4-2009$ on the Making East Kalimantan for leading energy center in Indonesia \\
& Medium Term Development Plan $2009-2013$ \\
& of East Kalimantan Province
\end{tabular}

3. East Kalimantan Governor Decree No. 670.12 / K.447 / 2013 on the Establishment of the The establishment of the Coordination Team, The Technical Coordination Team and the Technical Committee of Action and Alternative Energy Utilization

4. Regional regulation No. 7 - 2014 on the Regional Medium Term Development Plan (RPJMD) t Provinsi East Kalimantan Province $2013-2018$

5. Governor Regulation No. 17/ 2015 concerning Governance and licensing and Non-Licensing and Licensing Improving Governance in the sector of Mining, Forestry, and Palm Oil Plantation Committee of Action and Alternative Energy Utilization

Economic dependence on renewable and renewable natural resources and improved economic structure

Encouraging the development of renewable energy Ministry of Energy and Mineral Resources Regulates a moratorium on licensing of mining, plantation, and forestry

6. East Kalimantan Governor Decree No. 522 / K.227 / 2015 on the Establishment of BiomassBased Bioenergy Development Team in the Forestry Sector

(1) Composed master plan for the development of biomassbased energy,

(2) Dissemination of biomass-based energy development

(3) Mentoring process implementation biomass-based bioenergy development

(4) Providing advice and policy direction to smooth the implementation of biomass-based bio-energy development in the East Kalimantan forestry sector,

(5) Coordination and consultation to organizations / institutions relevant

7. Keputusan East Kalimantan Governor Decree Encouraging the local government of East Kalimantan to No. 522/K.526/2016 Establishment of the facilitate the formation of SF activities

Working Group on the Acceleration of Social Forestry (Pokja PPS): 


\subsection{Progress of Social Forestry Development in East Kalimantan}

Although various parties may view many internal and external factors as the cause of the lack of optimization of the extent of implementation of various social forestry schemes in Indonesia, particularly those related to $\mathrm{HKm}, \mathrm{HTR}, \mathrm{HD}$, and partnership, the development of social forestry in East Kalimantan is ongoing and continues to accelerate the process proposal. Until 2016, there are about twelve (12) Village Forests (HD) that have been established by the Decree of the Minister of Forestry and spread in three districts, namely in East Kutai, Berau, and West Kutai, with a total area of 27,030 ha (Annex Table 1).

While the total area in the proposing stage is 206,688.79 ha, located in several villages in East Kutai District and West Kutai District (Appendix Table 2), for community forest $(\mathrm{HKm})$ has been established $2 \mathrm{HKm}$ with a total area of 1990 ha in Balikpapan and East Kutai District (Appendix Table 1). For Community Plantation Forest (HTR) has been done reserve area located in East Kutai District of 4,150 ha and West Kutai District covering 5,790 ha, cooperating with several cooperatives. A $20 \%$ allocation for partnership in the IUPHHK-HTI area in East Kalimantan currently has 43 locations in 43 IUPHHK-HTI areas spread across several East Kalimantan districts.

From the results of the proposal's information, communication and coordination with related SKPD (Forestry Service in each District, BPDAS, KPH, and $\mathrm{BPKH}$ ) are done to complete the request. Mentoring and socialization efforts were also undertaken by several NGOs such as GTZ, WWF, Forclime, KBCF (Kawal Borneo Community Foundation), and Warsi to prepare the Management Plan and other file completeness.

Other strategic steps to achieve SF acceleration's objectives and targets are establishing Indicative Maps of Social Forestry Areas (PIAPS). PIAPS is a map of the allocation of SF management access for the community, which is developed jointly with the parties (Government, local government, and civil society) as a reference for HKm, HTR, HD, Kemitraan, and Customary Forest. From the data obtained that the area of PIAPS in East Kalimantan is in the protected forest (HL) of 80,943 ha, production forest (HP) of 175,910 ha, conservation forest (HK) 7,539 ha, limited production forest (HPT) of 67,906 ha, of the concession area of 328,484 ha so that the total area of PIAPS in East Kalimantan is 660,882 ha (Appendix Table 3).

\subsection{Obstacles and Challenges to Accelerate the Development of Social Forestry in East Kalimantan}

Although the development of social forestry is considered a unilaterally commanded and controlled one by the government (cf. KLHK) with officially offered schemes of HKm, HD, and HTR. These schemes are considered to be top-down design patterns, with minimal input from other parties, especially the community as the main actors. Now the local government has involved various parties (NGOs, private and local communities) and take a more participatory approach to accommodate the development of SF and management practices forest that has been practiced by the people of Merabu Village, Kec. Kelay, Kab. Berau with a site-based karst management model, with social forestry schemes involving government, community, and business / private parties.

The assumption that social forestry is still implemented in ideal considerations based on the bureaucracy of the national administration of forestry as well as patterns of industrial forestry, with procedures to be applied in the application of rights, utilization, and implementation permits to HKm, HTR, and HD, local government East Kalimantan continues to (1) simplify the complexity and even reduce the long and rigid bureaucracy among communities to gain rights and permits for the use of forests; (2) coordinate between the ministry of environment and forestry with other ministries/agencies including local governments; (3) preparing local institutional capacity at the village level and (4) escorting the plan after obtaining a permit in planning, implementation, provision of assistants for SF management community, creating networks to market SF products and products and allocating funds for SF financing. Field facilitation efforts are usually in international projects or programs run by nongovernmental organizations (NGOs) or cooperate with researchers/academics.

\section{CONCLUSION}

The efforts of the provincial government of East Kalimantan to support, encourage, and facilitate SF development's acceleration continues to be done by strengthening the roles and policies at the local government level. From the achievements described above, it is seen that the provincial government follows up the central government's policy dynamics to accommodate the social forestry schemes at the site level. However, it must be acknowledged that the area is not the only indicator that can be used in the context of "effectiveness" or the success of the roles and policies to accelerate the SF's development. The process towards making SF become the mainstream of a fairer and more sustainable forest management. Includes efforts to 
explore traditional/local forest/forest resource management practices to gain recognition.

\section{ACKNOWLEDGMENTS}

We are grateful to the Working Group of Social Forestry Acceleration (Pokja PPS) and their contributions and information. We are also thankful for the Social Forestry Initiative's multi-stakeholders in East Kalimantan', Forestry Service East Kalimantan Province, and East Kalimantan Provincial Government.

\section{REFERENCES}

[[1] FWI/GFW, Potret Keadaan Hutan Indonesia (The Portrait of Indonesia's forest situation), Forest Watch Indonesia dan Washington D.C.: Global Forest Watch, 2001.

[2] A. Justianto, Pilihan Strategi Pengurangan Kemiskinan di Sekitar Hutan: Studi Kasus di Kalimantan Timur. Jurnal Penelitian Sosial dan Ekonomi Kehutanan, Vol.5 No. 4, 2008.

[3] M.A. Sardjono, Membawa Perhutanan Sosial Indonesia ke Upaya Yang lebih Menjanjikan, dalam H. Kartodihardjo, Kembali Ke Jalan Lurus: Kritik Penggunaan Ilmu dan Praktek Kehutanan Indonesia, Forci Development, Nailil Printika, Yogyakarta, 2013.

[4] Peraturan Gubernur Nomor: 17 Tahun 2015 tentang Penataan dan Pemberian Izin dan Non Perizinan serta Penyempurnaan Tata Kelola Perizinan di Sektor Pertambangan, Kehutanan dan Perkebunan Kelapa Sawit, 2015.

[5] Peraturan Daerah No. 15 Tahun 2008 tentang Rencana Pembangunan Jangka Panjang Daerah Provinsi Kalimantan Timur Tahun 2005-2025, 2008.

[6] Peraturan Daerah No. 4 Tahun 2009 tentang Rencana Pembangunan Jangka Menengah Daerah Provinsi Kalimantan Timur Tahun 2009-2013, 2009.

[7] Peraturan Gubernur Kaltim No. 54 Tahun 2012 tentang Rencana Aksi Daerah Penurunan Emisi Gas Rumah Kaca Bidang Energi, Industri dan Transportasi tahun 2010 - 2020, 2012.

[8] Keputusan Gubernur Kaltim Nomor: 670.12/K.447/2013 tentang Pembentukan Tim Koordinasi dan Tim Teknis Aksi dan Pemanfaatan Energi Alternatif, 2013.

[9] Peraturan Daerah No. 7 Tahun 2014 tentang Rencana Pembangunan Jangka Menengah Daerah (RPJMD) Provinsi Kalimantan Timur Tahun 2013 - 2018, 2014.
[10] Keputusan Gubernur Kaltim No. 522/K.526/2016 tentang Pembentukan Kelompok Kerja Percepatan Perhutanan Sosial (Pokja PPS), 2016.

[11] Dinas Kehutanan, Paper pada Workshop Peluang Masyarakat Sipil Dalam Percepatan Dan Perluasan Perhutanan Sosial di Kalimantan Timur, Samarinda, 30 Mei 2017. 